\title{
Transition Metal Rates in Latosol Twice Treated With Sewage Sludge
}

\author{
Ana Tereza Jordão Pigozzo ${ }^{1}$, Ervim Lenzi ${ }^{2 *}$, Jorge de Luca Junior ${ }^{3}$, Carlos Alberto \\ Scapim $^{4}$ and Antonio Carlos Saraiva da Costa ${ }^{4}$ \\ ${ }^{I}$ Faculdade de Ciências Agrárias e Veterinárias - FCAV; Universidade Estadual Paulista - UNESP; Botucatu - SP - \\ Brasil. ${ }^{2}$ Departamento de Química - DQI; Universidade Estadual de Maringá - UEM; Maringá - PR - Brasil. \\ ${ }^{3}$ Departamento de Engenharia Rural; Faculdade de Ciências Agrárias e Veterinárias - FCAV; Universidade \\ Estadual Paulista - UNESP; Jaboticabal - SP - Brasil. ${ }^{4}$ Departamento de Agronomia - DAG; Universidade \\ Estadual de Maringá - UEM; Maringá - PR - Brasil
}

\begin{abstract}
Agricultural recycling of sewage sludge has been a source of accumulation of heavy metals in the environment which may reach toxic levels and cause serious damage to the biota. Field experiments were undertaken for two agricultural years (2000 and 2002) and effects of two sewage sludge applications were evaluated through the extraction of (essential and non-essential) transition metals by diethylenetriaminepentaacetic acid (DTPA) extractor in a medium texture dystrophic Dark Red Latosol. $\mathrm{Cd}, \mathrm{Ni}, \mathrm{Co}, \mathrm{Pb}$ and $\mathrm{Cr}$ were not detected. Application of sewage sludge initially caused a slight $\mathrm{pH}$ rise in the soil; later $\mathrm{pH}$ lowered and kept itself close to the starting level. It could be concluded that through consecutive sludge application, extractable rates of Fe and Mn in soil samples gradually increased during the two agricultural years in proportion to sewage sludge doses and sampling period. In fact, they were higher than rates of control. Due to low concentrations of soil samples, extractor had a restricted capacity for evaluation of its phytoavailability.
\end{abstract}

Key words: Heavy metals, sewage sludge, DTPA, biosolid, nutrient rates

\section{INTRODUCTION}

In mankind's efforts to find a suitable place for different types of residues disposal, agricultural recycling has frequently been the best option to produce large quantities of nutrients, improve the chemical, physical and biological qualities of soil and find a solution to dispose of large quantities of wastes. Although sewage sludge is a nutrient source for soil, it is also highly risky. Besides lixiviation of nitrates and the accumulation of heavy metals in the non-homogenized soil, sewage sludge may also be a source of disease that may be transmitted by water. Biosolids may contain harmfull elements, especially pathogens, persistent and toxic organic substances, excessively nitrogenized compounds and heavy metals, which restrict their use in agriculture (Andreoli and Fernandes 1997). Successive applications of sewage sludge may cause an accumulation of toxic agents, especially heavy metals. Since the latter are non-degradable, they are of major concern for environmental safeness necessary for such practice. Depending on to their availability in their solution in soil, these compounds may directly contaminate soil organisms and plants at phytotoxic levels, transfer their pollutants to the food chain through plants and their fruit or through

\footnotetext{
${ }^{*}$ Author for correspondence
} 
the contamination of surface or under-surface waters (Chang, 1987).

Many authors, (Chang et al., 1997; Raij, 1998) have discussed restriction in the agricultural use of biosolids, mainly heavy metals. Page et al. (1987) reviewed studies on the subject, providing important information on the behavior of heavy metals added to the soil-plant system through sludge. Two relevant aspects could be identified: sewage sludge is a source and, at the same time, an immobilizing agent of heavy metals in the soil. Further, absorption of heavy metals by plants in proportion to the residue's application rates has different responses.

Nutrient or non-nutrient metal rates available in the soil's solution are low and dependent on certain variables, such as $\mathrm{pH}$, levels of organic matter and clay, soil mineralogy, competitions for other cations in absorption sites, soil temperature and humidity. Availability decreases at low temperatures and humidity (Petruzzelli, 1989; Hooda and Alloway, 1996). Immobilization of metals in the soil is caused by the formation of slightly soluble compounds with a group of anions in the soil and by the formation of complexes with the active sites of the soil's organic substances, among which may be mentioned humus components. $\mathrm{pH}$ plays an important role among the above variables in the formation or suppression of active sites.

$\mathrm{pH}$ in soil may be changed by various agents. The type of biosolid incorporated to the soil may cause alterations in $\mathrm{pH}$ (Gloria, 1992). As a general rule, its addition increases $\mathrm{pH}$ and the soil's negative charges (Dias, 1994; Marques, 1996). Berton et al. (1989) showed the effect on the behavior of $\mathrm{pH}$ in various soil types when increasing doses of biosolid are added. Alkalinized sewage sludge has neutral and alkaline $\mathrm{pH}$ and is able to increase the residues's $\mathrm{pH}$. Another $\mathrm{pH}$ modifier is the environmental microbiological activity with the formation of inorganic and organic acids. Research by Pietz et al. (1989) and Dowdy et al. (1991) stated that certain types of sewage sludge may acidify the soil. Reactions of nitrification of ammoniac nitrogen, the probable oxidation of sulfites, and the production of organic acids during the degradation of residues may account for such acidification. Logan et al. (1997) reported a decrease in $\mathrm{pH}$ for the lowest sewage doses immediately after the application of residues in calcareous rock-derived soil during the first year of application of sewage sludge (without any previous treatment with lime).

The $\mathrm{pH}$ of the soil is one of the most important factors in the control of the bioavailability of metals. These are more unstable in low $\mathrm{pH}$, due to the displacement of the metallic cations by the protons, to the occurrence of hydrolyzed species of hydroxides and to the solubility of other solid mineral phases, such as carbonates and phosphates (Logan and Chaney, 1983). The availability of metals tends to be smaller in the case of high $\mathrm{pH}$, due to the formation of precipitates, very strong adsorption and the increase of the stability of compounds with humus substances (Petruzzelli, 1989).

Since Brazilian soils are different from those in temperate zones, greater concern is required in the extrapolation of metals that may be incorporated to them, because these soils are generally acid, with low cation-exchange capacity (CEC) and low contents of organic matter. Soils classified as latosols, (Curi et al., 1993) are: normally compact soils, generally formed in humid tropical regions, characterized to present low molecular relation of $\mathrm{SiO}_{2} / \mathrm{Al}_{2} \mathrm{O}_{3}$ (or silica/sesquioxides) in the clay fraction, low cation-exchange capacity (CEC), low clay activity, low content of primary minerals easily decomposed by the physical, chemical and biological conditions and low content of soluble constituents. The dystrophic dark red latosol is a poor nutrient-soil, which presents low saturation of base (SB).

Since few researches have been undertaken involving the addition of metals through organic residues, no agreement exists with regard to sewage sludge doses and their frequency of application in cultures. Their composition is not constant and there are some difficulties in foreseeing the behavior of certain metals vis-à-vis soil types. Actually these facts restrict the application of higher doses of residues. This work used a medium texture dystrophic Dark Red Latosol, which, in the past, was alternatively utilized to cultivate maize and bean, and evaluated the effects of two times applications of sewage sludge on the availability of transition metals

\section{MATERIALS AND METHODS}

General characteristics of site, soil and sewage

Field experimental work was undertaken in the Experimental Farm of the State University of 
Maringá, at Iguatemi, municipality of Maringá PR Brazil during the agricultural years 2000-2001 and 2001-2002. Site, with a slightly rolling relief, lies at $23^{\circ} 25^{\prime} 00^{\prime \prime S}$; $51^{\circ} 25^{\prime} 00^{\prime \prime} \mathrm{W}$; at $555 \mathrm{~m}$ above sea level. Soil belongs to the large group of dystrophic Dark Red Latosols with medium clay texture. Rates of fine sand, thick sand, silt and clay were $570,280,20$ and $130 \mathrm{~g} \mathrm{~kg}^{-1}$ respectively. Sewage sludge, resulting from an anaerobic fluidized bed reactor, came from Sewage Treatment Station STS-1, of the Paraná Water Supply Company (SANEPAR), Maringá PR Brazil. Tempered and stored sewage sludge was solid at the moment of collection, with its natural humidity and without any addition of lime. A representative sample was collected to determine its humidity and chemical characteristics.

Three aliquots of known mass were removed to determine their humidity. They were dried in buffers at $65^{\circ} \mathrm{C}$ till constant weight. Humidity was determined by difference of mass, whereas the amount of humid sewage sludge needed to be distributed in each experimental unit was calculated to obtain the doses for the different treatments applied to the soil (Andreoli and Bonnet, 1998). Aliquots (10 g) of recently collected in natura sewage sludge were separated to determine $\mathrm{pH}$, following Andreoli and Bonnet (1998).

To determine the chemical composition of the sewage sludge, a composite sample was dried, ground, homogenized and sieved. The resulting sample was reduced to constant mass. Nutrient and non-nutrient metals were determined. $0.5000 \mathrm{~g}$ aliquots were humidly decomposed with a nitricperchloric mixture, in a digester. Metal concentrations were determined by atomic absorption method, flame mode (Welz and Sperling, 1999). Kjeldahl and thermal decomposition gravimeter methods were used to determine nitrogen and organic matter, respectively (Horwitz, 1980). Whereas Table 1 presents results, Table 2 shows heavy metals analyzed.

\section{Experiment}

Field experiment was performed in a randomized experimental block design in subdivided lots, with four repetitions. Doses $\left(0,6,20,40,60,80 \mathrm{t} \mathrm{ha}^{-1}\right)$ of sewage sludge were distributed in lots and sampling time $(0,30,60,90$ and 120 days $)$ was fixed for each sub-lot. Each block consisted of six experimental units. Sub-lots consisted of five 23 m-long rows, spaced $1.0 \mathrm{~m}$ between the row and $0.20 \mathrm{~m}$ between plants. Although totaling $115 \mathrm{sq}$. m., used area for sampling soil and plants consisted of 3 internal rows of $20 \mathrm{~m}$ and totaled 60 sq. m. Sewage sludge was applied on the surface with spade and hoe. Incorporation was done by harrowing at approximately $0-20 \mathrm{~cm}$ depth in both applications.

\section{Duration of the experiment}

The experiment was carried out along two agricultural years. In the first (2000-2001) the applications of the sewage sludge doses: $0,6,20$, $40,60,80 \mathrm{t} \mathrm{ha}^{-1}$ in the following periods: $0,30,60$, 90 and 120 days were evaluated with four repetitions. In the second agricultural year (20012002) the application of the same sewage sludge doses, in the followings periods: 0, 60, 90 and 120 days, were evaluated with four repetitions. During the two agricultural years, the immediate effects of the two sludge application, summer harvest and the residual effect of the two application winter harvest, were evaluated.

\section{Collection, preparation and analysis of soil samples}

At $0,30,60,90$ and 120 days after incorporation of sewage sludge in the two agricultural years collection of soil samples of each one of the six experimental units was undertaken. The six units comprised 5 treatments and 1 control for each randomized block at a $0-20 \mathrm{~cm}$ depth layer. A sample composed of 4 simple samples came from each sub-lot. Samples were identified, air dried, filtered through $2 \mathrm{~mm}$-hole polypropylene sieves, homogenized and stored as Air Dried Fine Earth (ADFE).

\section{Analysis of soil characterization}

ADFE samples were analyzed routinely for usual parameters following IAPAR (1992): pH was determined in $\mathrm{CaCl}_{2}$ solution; potential acidity or $\left[\mathrm{H}^{+}+\mathrm{Al}^{3+}\right]$ was determined with the Shoemaker, Mclean and Pratt or SMP buffer solution; P, K and $\mathrm{Na}$ were determined in the soil solution extracted with Mehlich solution, and P determined by UV$\mathrm{Vis}$ method, $\mathrm{K}$ and $\mathrm{Na}$ determined by atomic absorption method; $\mathrm{Ca}, \mathrm{Mg}$ were determined by atomic absorption method in the soil solution extracted with $\mathrm{KCl} 1,0 \mathrm{~mol} \mathrm{~L}^{-1}$ solution; the concentration of $\mathrm{C}$ was determined by the WakleyBlack method, $\mathrm{N}$ by Kjeldhal method and $\mathrm{S}$ determined by sulfate turbidimetric method. The 
value denominated by Sum of Bases (SB) was calculated with the equation [01]. The result is expressed in $\mathrm{cmol}_{\mathrm{c}} \mathrm{dm}^{-3}$ units.

SB

$$
=\mathrm{Ca}^{2+}+\mathrm{Mg}^{2+}+\mathrm{K}^{+}+\mathrm{Na}^{+}
$$

The CEC values were determined by equation [02] in $\mathrm{cmol}_{\mathrm{c}} \mathrm{dm}^{-3}$ units.

$$
\mathrm{CEC}=\mathrm{SB}+\left[\mathrm{H}^{+}+\mathrm{Al}^{3+}\right]
$$

Table 3 shows results for soil samples, without treatment, at time 0 of incorporation.

\section{Analysis of total rates of metals in the soil}

Total rates of metals in the soil were determined by their respective concentrations by atomic absorption in the solution obtained from the decomposition of samples, humidity mode, using a mixture of $\mathrm{HNO}_{3}$ and $\mathrm{HClO}_{4}$ (Horwitz, 1980).

\section{Analysis of available rates of metals in the soil}

Soluble rates of metals, available for plants in soil were determined by their respective concentrations of metals by atomic absorption, in the solution obtained from the extraction of $20.0000 \mathrm{~g}$ of ADFE with $40 \mathrm{~mL}$ of extracting mixture comprising DTPA (diethylenetriaminepentaacetic acid) $0.005 \mathrm{~mol} \mathrm{~L}^{-1}+$ TEA (triethanolamine) 0.1 mol L ${ }^{-1}+\mathrm{CaCl}_{2} 0.01 \mathrm{~mol} \mathrm{~L}^{-1}$, corrected to $\mathrm{pH} 7.3$ (Lindsay and Norwell, 1978).

\section{Statistical analysis}

The conventional statistical method was employed for sub-lots for each period. Surface response methodology was used for regression analysis. It was done from the square polynomial model with two independent variables, according to equation [03] (Regazzi and Campos, 1988).

$$
\begin{aligned}
\mathrm{Y}_{\mathrm{i}}= & \mathrm{B}_{\mathrm{O}}+\mathrm{B}_{1} \mathrm{~N}_{\mathrm{i}}+\mathrm{B}_{2} \mathrm{~T}_{\mathrm{i}}+\mathrm{B}_{3} \mathrm{~N}_{\mathrm{i}}^{2}+\mathrm{B}_{4} \mathrm{~N}_{\mathrm{i}} \mathrm{T}_{\mathrm{i}}^{2}+[03] \\
& \mathrm{B}_{5} \mathrm{~N}_{\mathrm{i}} \mathrm{T}_{\mathrm{i}}+\mathrm{E}_{\mathrm{i}}
\end{aligned}
$$

where: $Y_{i=}$ variable responses; $N_{i}$ biosolid levels; $\mathrm{T}_{\mathrm{i}}=$ time levels; $\mathrm{E}_{\mathrm{i}}=$ randomized error; $\mathrm{B}_{\mathrm{i}}$ with $\mathrm{i}$ $=0,1,2, \ldots, 5=$ parameters to be estimated.

The complete model above shows that the equation with the best adjustment to data was based on the coefficient of determination (CD), or $\mathrm{r}^{2}$, in the context of the regression coefficient by Student's $t$ test (up to $10 \%$ probability) and by analysis of residues. Since only three evaluations were undertaken during the second agricultural year, the mathematical model was formula [04]

$$
\mathrm{Y}_{\mathrm{i}}=\begin{aligned}
& \mathrm{B}_{\mathrm{O}}+\mathrm{B}_{1} \mathrm{~N}_{\mathrm{i}}+\mathrm{B}_{2} \mathrm{~T}_{\mathrm{i}}+\mathrm{B}_{3} \mathrm{~N}_{\mathrm{i}}^{2}+[04] \\
& \mathrm{B}_{4} \mathrm{~N}_{\mathrm{i}} \mathrm{T}_{\mathrm{i}}^{2}+\mathrm{E}_{\mathrm{i}}
\end{aligned}
$$

\begin{tabular}{|c|c|c|c|c|c|c|c|c|c|}
\hline \multirow[t]{2}{*}{ Sewage sludge } & $\mathbf{N}$ & $\mathbf{C}$ & $\mathrm{OM}(\%)$ & $\mathrm{C}: \mathrm{N}$ & Mn & $\mathbf{C u}$ & $\mathbf{Z n}$ & $\mathbf{F e}$ & \multirow[t]{2}{*}{$\mathbf{p H}(*)$} \\
\hline & $\longleftarrow$ & 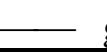 & \multicolumn{2}{|l|}{$\mathrm{g} \mathrm{kg}^{-1}$} & $\longleftarrow$ & \multicolumn{2}{|c|}{$-\mathrm{mg} \mathrm{kg}^{-1}-$} & $\longrightarrow$ & \\
\hline $1^{\text {st }}$ application & 37.0 & 264.0 & 405.0 & $7: 1$ & 274.1 & 480.0 & $1,320.0$ & $42,800.0$ & 4.68 \\
\hline $2^{\text {nd }}$ application & 32.2 & 235.8 & 406.5 & $8: 1$ & 298.0 & 450.00 & $1,540.0$ & $48,600.0$ & 4.72 \\
\hline
\end{tabular}

\section{RESULTS AND DISCUSSION}

The results of the chemical analysis of sewage

\begin{tabular}{|c|c|c|c|c|c|}
\hline Sewage sludge & Cd & $\begin{array}{c}\mathbf{N i} \\
\longleftarrow\end{array}$ & $\mathrm{Cr}$ & $\begin{array}{l}\text { Co } \\
\left(\mu g^{-1}\right)\end{array}$ & $\mathbf{P b}$ \\
\hline $1^{\text {st }}$ application & 2.8 & 88.0 & 72.5 & 72.5 & 492.0 \\
\hline $2^{\text {nd }}$ application & 2.1 & 142.0 & 125.0 & 125.0 & 380.0 \\
\hline
\end{tabular}
sludge and soil are presented in Tables 1-3.

Table 1 - Averages of chemical characteristics of sewage sludge used in the experiment, associated to soil fertility (†).

Table 2 - Concentration of heavy metals non-essential for plants in the sewage sludge in soil treatments $(\dagger)$.

$(\dagger)$ - Analyses were undertaken at the Agrochemical and Environment Lab of the State University of Maringá. 
Table 3 - Chemical characteristics of soil used in experiments.

\begin{tabular}{|c|c|c|c|c|c|c|c|c|c|c|c|}
\hline $\begin{array}{c}\text { Soil } \\
(0-20 \mathrm{~cm})\end{array}$ & $\underset{\mathrm{CaCl}_{2}}{\mathrm{pH}}$ & $\begin{array}{l}\mathbf{P} \\
\leftarrow \mathrm{n}\end{array}$ & $\mathrm{Im}^{-3} \rightarrow$ & & $\mathrm{g}^{-1} \rightarrow$ & Ca & Mg & $\begin{array}{c}\mathbf{K} \quad \mathbf{H}^{+}+\mathbf{A l}^{3+} \\
(\dagger) \\
\mathrm{cmol}_{\mathrm{c}} \mathrm{kg}^{-1}\end{array}$ & $\underset{(\$)}{\text { CEC }} \quad$ SB & C:N & V\% \\
\hline dDRL & 5.0 & 1.8 & 6.6 & 0.6 & 7.6 & 3.58 & 0.88 & 3.42 & 7.96 & $12: 1$ & 57.0 \\
\hline
\end{tabular}

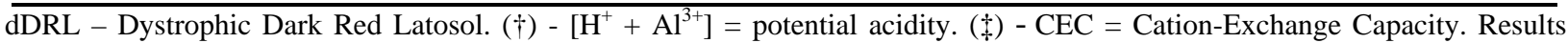
above are mean of analyses done in two repetitions. $\mathrm{SB}=$ Saturation of base.

\section{CEC and pH}

Regression analysis (Fig. 1) showed that sewage sludge dose significantly affected the soil's CEC. Variance analysis of the soil's CEC, (data not presented) also showed that significant effects only occurred in the two agricultural years due to sewage sludge doses. CEC increased because of residual doses in the two agricultural years (Fig. 1). Variable had a linear trend in Harvests 1 and 2 during the first year (2000-2001), and in Harvest 3 , during the second year (2001-2002). However, Harvest 4, during the second year (2002), average $7.16 \mathrm{cmol}_{\mathrm{c}} \mathrm{dm}^{-3}$, failed to show any significant effect from treatments. Due to residual doses, CEC increase had a linear design (Fig. 1). Variable's behavior showed an increasing linear trend when $0.0272 \mathrm{cmol}_{\mathrm{c}} \mathrm{dm}^{-3}$ for each dose of $1 \mathrm{t} \mathrm{ha}^{-1}$ of residue were added to the soil. An increase in CEC caused by sewage sludge application was also suggested by Melo et al. (1994); Cavallaro et al. (1993). Who reported a CEC increase due to sewage sludge application in doses between 0 and $240 \mathrm{t} \mathrm{ha}^{-1}$ (dry base). Increase was attributed to the fact that organic matter has active sites, with a capacity for linking and exchanging ions, according to their $\mathrm{pH}$. Carboxylic, phenol, carbonyl, alcohol, amino and other groups integrated the sites, which was directly proportionate to the quantity of organic matter. Although results from the application of increasing doses of sewage sludge on soil's $\mathrm{pH}$ had a significant effect (Fig. 2), adjustment of adequate regression model failed.
$\mathrm{pH}$ increased up to level $6 \mathrm{t} \mathrm{ha}^{-1}$ and stabilized itself for other doses at Harvest 1.

In Harvest 2 of the same year, a pH decrease occurred when residual doses increased. Residue affecting $\mathrm{pH}$ of soil decrease stabilized during harvest and maintained itself close to start.

Since residue affected $\mathrm{pH}$ of soil and such effect decreased in time, this fact suggested that nitrification, a phenomenon accounting for $\mathrm{pH}$ decrease, was restricted by the environment's acidity. Logan et al. (1997) reported a decrease in $\mathrm{pH}$ for the lowest doses of sludge, 7.5 and $15 \mathrm{t} \mathrm{ha}$ ${ }^{1}$, in soil from calcareous rocks during the first year of non-treated sludge with lime. Nitrification reactions of ammoniacal nitrogen for rise in $\mathrm{pH}$ in the highest doses and reactions were responsible involved in the degradation of the residue's organic charge for the verified acidification.

Oliveira (2000) and Bertoncini and Mattiazzo (1999) reported an increase in $\mathrm{pH}$ rates when increasing biosolid doses were added. The alkalinity of the material was responsible for $\mathrm{pH}$ increase. Difference in results was associated to different characteristics of sewage sludge used in the different experiments. Harvests 3 and 4 (Fig. 2) during the second year showed no significant effect on $\mathrm{pH}$ (average $\mathrm{pH} 4.40$ and 4.35, respectively) in proportion to the levels of sewage sludge applied and to the culture's time of development. 


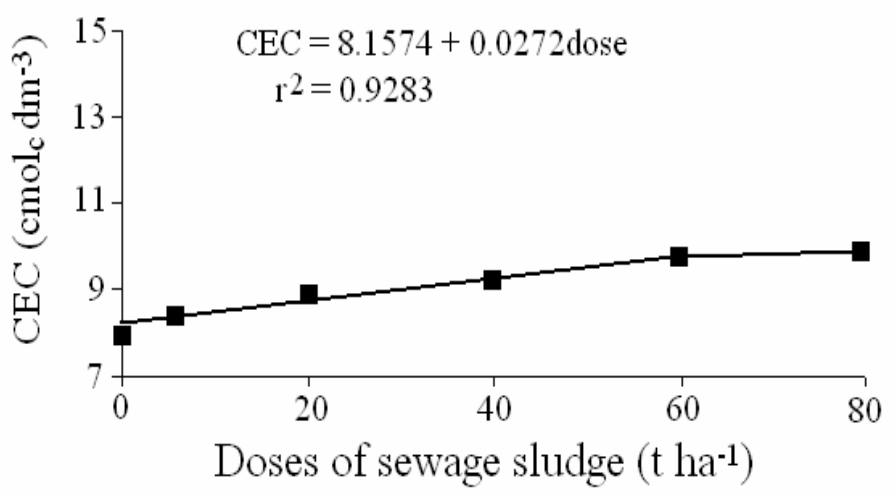

(a) Harvest 1 (conventional or Summer harvest)

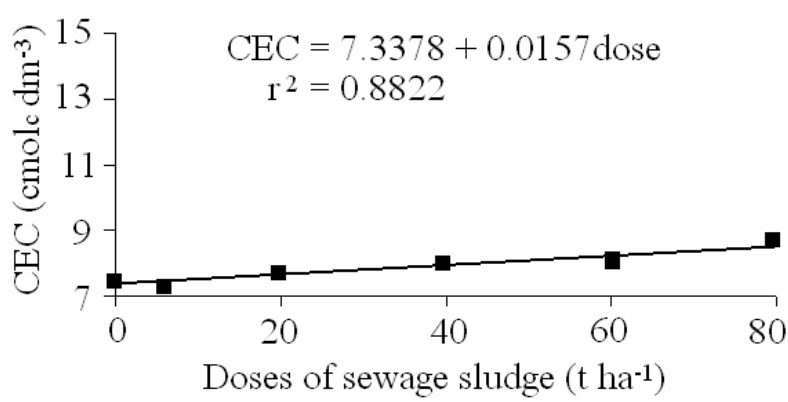

(b) Harvest 2 (Winter harvest)

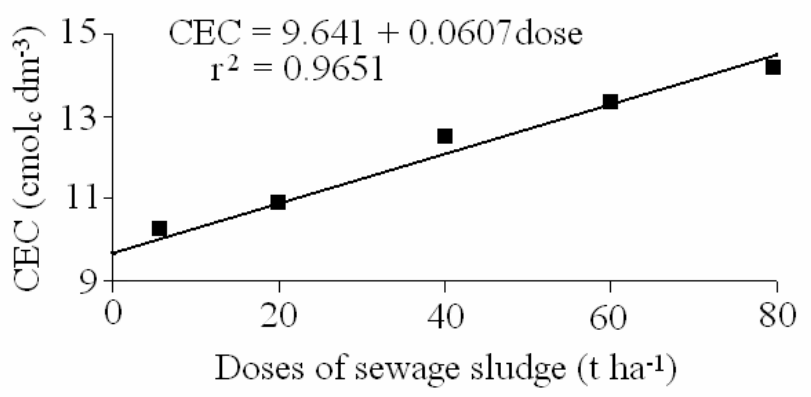

(c) Harvest 3 (conventional or Summer harvest)

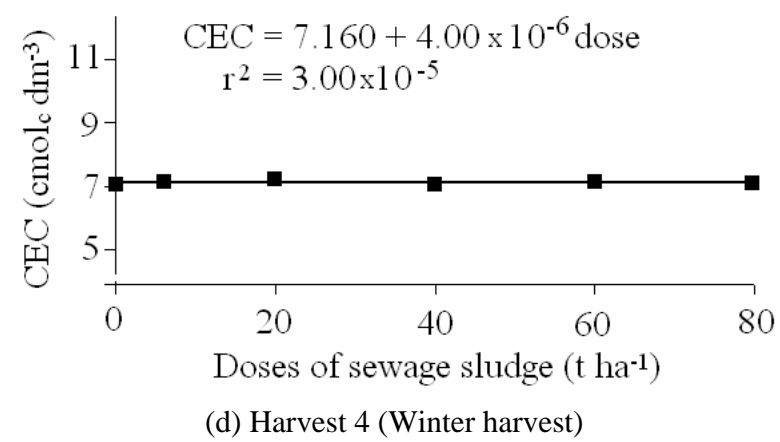

Figure 1 - Cation Exchange Capacity (CEC) of the soil during agricultural years 2000-2001 and 20012002, Harvests 1 (a) - conventional or Summer harvest, 2 (b) - Winter harvest; 3 (c) conventional or Summer harvest and 4 (d) - Winter harvest, due to increasing doses of sewage sludge. 


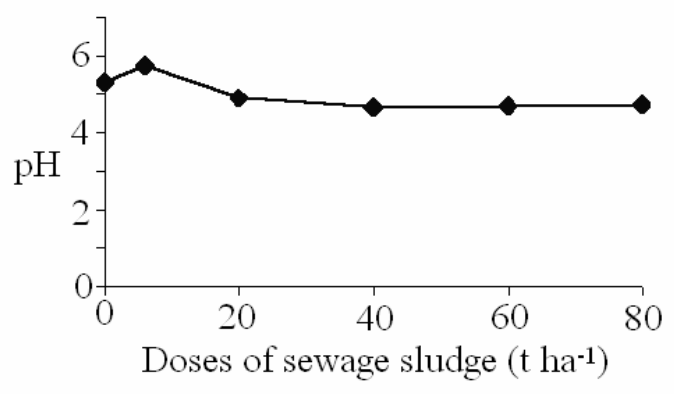

(a) Harvest 1(conventional or Summer harvest)

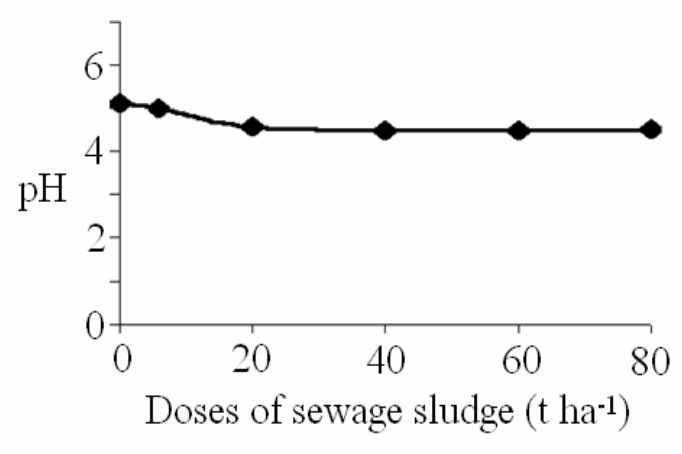

(b) Harvest 2 (Winter harvest)

(c) Harvest 3 (conventional or Summer harvest) Mean: $\mathrm{pH}=4.40$

(d) Harvest 4 (Winter harvest) - Mean: $\mathrm{pH}=4.35$

Figure 2 - Mean rates of pH of soil during agricultural years 2000-2001 and 2001-2002, in harvests $1(\mathrm{a}), 2$ (b), and mean rates of $\mathrm{pH}$ in harvests 3 (c) and 4 (d), in proportion to increasing doses of sewage sludge.

Table 4 - Mean rates of Fe and Mn, extracted by DTPA-TEA, obtained from analytic result averages of 5 samples from soil collected during periods $0,30,60,90$ and 120 days of biosolid incorporation, by increasing doses of sewage sludge.

\begin{tabular}{|c|c|c|c|c|c|c|c|}
\hline \multirow{2}{*}{$\begin{array}{c}\text { Agricultural } \\
\text { year }\end{array}$} & \multicolumn{6}{|c|}{ Doses of sewage sludge $\mathrm{t} \mathrm{ha}^{-1} *$} & \multirow{2}{*}{$\begin{array}{l}\text { CD } \\
\left(\mathbf{r}^{2}\right)\end{array}$} \\
\hline & $\mathbf{0}$ & $6(12)$ & $20(40)$ & $40(80)$ & $60(120)$ & $80(160)$ & \\
\hline & & & \multicolumn{3}{|c|}{$\mathrm{Fe}\left(\mathrm{mg} \mathrm{kg}^{-1}\right)$} & & \\
\hline 2000-IE & 27.06 & 35.91 & 51.85 & 71.45 & 85.62 & 94.32 & 0.97 \\
\hline 2001-RE & 28.19 & 40.16 & 57.66 & 83.87 & 97.10 & 105.19 & 0.95 \\
\hline 2001-IE & 31.15 & 47.94 & 74.55 & 97.72 & 108.00 & 129.36 & 0.93 \\
\hline 2002-RE & 34.53 & 58.15 & \multicolumn{3}{|c|}{$\operatorname{Mn}\left(\mathrm{mg} \mathrm{kg}^{-1}\right)$} & 140.08 & 0.98 \\
\hline 2000-IE & 17.88 & 18.80 & 19.82 & 21.96 & 25.84 & 28.28 & 0.88 \\
\hline 2001-RE & 20.45 & 21.90 & 24.18 & 26.12 & 29.84 & 33.02 & 0.97 \\
\hline 2001-IE & 22.70 & 26.70 & 33.30 & 37.86 & 42.83 & 46.29 & 0.95 \\
\hline 2002-RE & 27.05 & 34.63 & 42.47 & 50.01 & 54.53 & 58.81 & 0.98 \\
\hline
\end{tabular}

\footnotetext{
* doses between brackets are for 2001/02; IE: Immediate Effect ( $1^{\text {st }}$ and $3^{\text {rd }}-$ Conventional Harvest); RE: Residual Effect $\left(2^{\text {nd }}\right.$ and $4^{\text {th }}$ - Winter Harvest). CD - Coefficient of Determination or $\mathrm{r}^{2}$.
} 
Heavy Metals (non-essential elements): $\mathrm{Cd}, \mathrm{Cr}$, $\mathrm{Ni}, \mathrm{Co}$ and $\mathrm{Pb}$

Table 2 showed $\mathrm{Cd}, \mathrm{Cr}, \mathrm{Ni}, \mathrm{Co}$ and $\mathrm{Pb}$ in sewage sludge when total decomposition of the sample by nitro-perchlorate mixture was performed. However, these heavy metals failed to be detected when soil extraction was undertaken with sewage sludge applied yearly, $(12,40,80,120$ and $160 \mathrm{t}$ $\left.\mathrm{ha}^{-1}\right)$, corresponding to different treatments during the two agricultural years with extractor DTPATEA. Or, rather, their concentrations were below the method's detection level (Long and Winefordner, 1983).

Oliveira (1995) and Bertoncini (1997) also failed to show $\mathrm{Cr}$ removal by DTPA solution. When Anjos (1999) worked with Dark Red Latosol and Red Latosol treated with different sludge doses, totaling $388 \mathrm{t} \mathrm{ha}^{-1}$ (dry base), it was found that $\mathrm{Cd}$ and $\mathrm{Pb}$ rates evaluated by DTPA-TEA extractor were below the method's detection limit. In field work, Oliveira (2000) evaluated the phytoavailability of heavy metals in Red Latosol, treated with 33, 66 and $99 \mathrm{tha}^{-1}$ of sewage sludge (dry base) during the first year and with 37, 74 and $110 \mathrm{t} \mathrm{ha}^{-1}$ (dry base) in the second year. $\mathrm{Cd}, \mathrm{Cr}$ and $\mathrm{Pb}$ rates, evaluated by three extractors (one of them was DTPA-TEA) were below the analytic method's detection limit. In a Red Argisol treated with $0,10,20,30,40$ and $50 \mathrm{t} \mathrm{ha}^{-1}$ of sewage sludge (dry base) in a green house, Simonete (2001) showed that $\mathrm{Cd}, \mathrm{Ni}, \mathrm{Pb}$ and $\mathrm{Cr}$ rates, extracted by DTPA-TEA, were below the method's detection limits for all treatments.

\section{Evaluation of available rates of $\mathrm{Fe}$ and $\mathrm{Mn}$ in soil}

Amounts of Fe and Mn removed from soil samples by extracting solution increased in proportion to the doses of sewage sludge and occurred in the following sequence $\mathrm{Fe}>\mathrm{Mn}$. This showed rates in sewage sludge (respectively, 42,800 and 48,500 $\mathrm{mg} \mathrm{kg}{ }^{-1}$ ) and doses incorporated in the soil (Table 4). This could be accounted for the concentrations of metals in the residue. Average increases in rates of elements available were reported when compared to those of control. Table 4 presents the variations from the lowest to the highest dose for the four harvests, or rather, Fe: 33 to $249 \%$; 42 to $273 \%$; 54 to $315 \%$; 68 to $306 \%$, respectively. This has also been reported by Simonete (2001), who applied sewage sludge in soil cultivated with corn in a green house and registered a greater increase in Fe rates. The increase was attributed to the high metal rate in the residue.

If amounts of the above metals in the soil during the first agricultural year $\left(1^{\text {st }}\right.$ and $2^{\text {nd }}$ harvests) were taken into account, average $\mathrm{Fe}$ and $\mathrm{Mn}$ extraction in treatments with sewage sludge doses was estimated at 7 and $120 \%$, respectively, for DTPA. During the second agricultural year $\left(3^{\text {rd }}\right.$ and $4^{\text {th }}$ harvest) rates changed to 5 and $218 \%$, respectively (Table 4 ).

$\mathrm{Fe}$ and $\mathrm{Mn}$ rates from soils by the extractor were mainly affected by doses and periods with metal increase (Figs. 3 and 4).

In the case of manganese, DTPA solution extracted 120 and $218 \%$, respectively. In the case of $\mathrm{Mn}^{2+}$ removal, when rates of the metal in treatments were compared with and without sewage sludge, Anjos (1999) reported a significant difference with extractor DTPA pH 7.3. Lowest rates of $\mathrm{Mn}^{2+}$ were extracted from treatments with biosolid. Such behavior was also registered by Silva (1995) and was related to final $\mathrm{pH}$ of the treatments. It was actually higher ( $\mathrm{pH} 7.4)$ than that of controls ( $\mathrm{pH} 4.8$ ).

\section{Manganese}

Variance analysis showed that availability of manganese in the soil had significant effects on sewage sludge doses and sampling periods, although no interaction between these factors was observed (Fig. 3). In proportion to residue doses and sampling periods, rate increase was linear during the agricultural years 2000-2001 and 20012002 for the four harvests (Figs. 3a, b, c, d). 


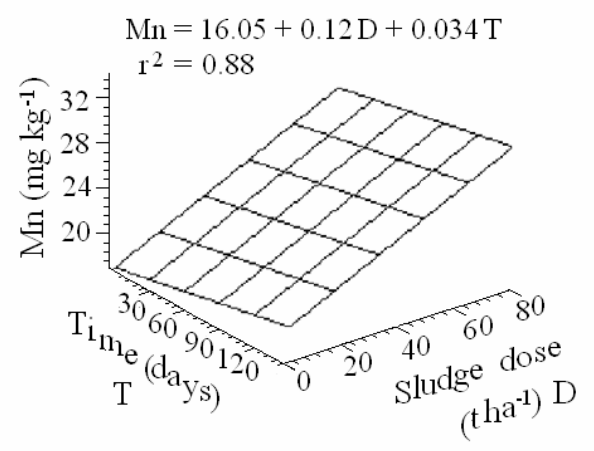

(a) Harvest 1 (conventional or Summer harvest)

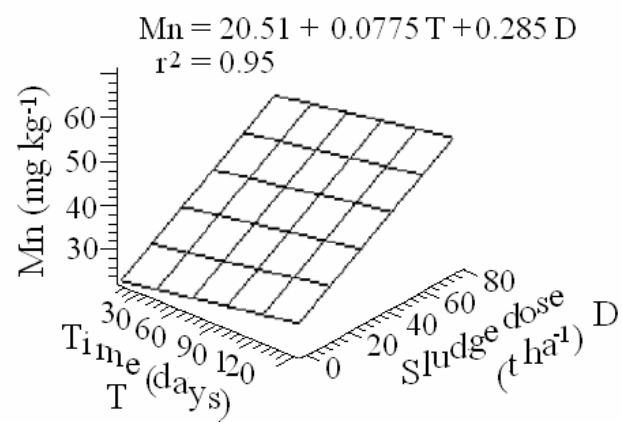

(c) Harvest 3 (conventional or Summer harvest)

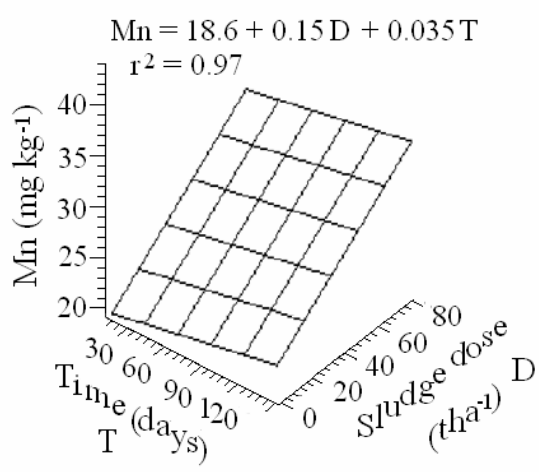

(b) Harvest 2 (Winter harvest)

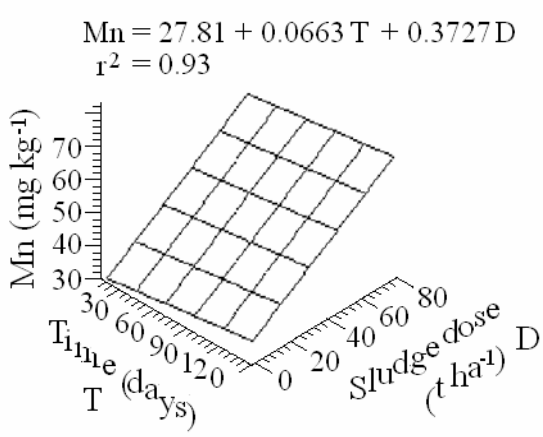

(d) Harvest 4 (Winter harvest)

Figure 3 - Variation of average rates of Mn (a) Harvest 1, (b) Harvest 2, (c) Harvest 3 e (d) Harvest 4 , removed by DTPA pH 7.3 in proportion to the sewage sludge in the four harvests.

Availability of $\mathrm{Mn}$ in the soil mainly depends on $\mathrm{pH}$, oxy-reduction potential, organic matter and balance with other cations. Soil $\mathrm{pH}$ is one of the chief factors that controls availability. Liming triggers oxidation of $\mathrm{Mn}^{2+}$ to a higher valence and lower solubility. Complexation of organic matter may also account for a decrease in the element's availability through liming (Borkert et al., 2001). In the case of Quartz Sand and Dark Red Latosol, $\mathrm{pH}$ adjusted to 3.9 and 4.9 and then treated with 0 ; 13.5; 29.7 and $40.5 \mathrm{t} \mathrm{ha}^{-1}$, Oliveira (1995) found that solution of $\mathrm{HCl} 0.1 \mathrm{~mol} \mathrm{~L}^{-1}$ and DTPA extracted larger amounts of $\mathrm{Mn}$ than those added to soil through sewage sludge. High $\mathrm{pH}$ rates favored the formation of more stable organic compounds. Activity of microorganisms that oxidizes soluble Mn to unavailable forms reached its peak at pH 7.0 (Tisdale et al., 1985).

\section{Iron}

By variance analysis, iron presented an increasingly linear trend between time and sewage sludge doses applied to the soil for the agricultural year 2000-2001 (Figs. 4a and b). Since similar data were found in Harvests 3 and 4 of the second year, Fe showed an increasingly linear trend both in doses and in time (Figs. 4c and d). Availability of element was higher during the second agricultural year in the two harvests. This was due to the cumulative effect of two sewage sludge applications to the soil with high concentrations of the element in the residue and $\mathrm{pH}$ increase. Availability of the element decreased with a rise in pH (Matos et al., 1996).

$\mathrm{pH}$ influences the solubility of $\mathrm{Fe}$ compounds. According to Pigozzo et al. (2000), average rates of $\mathrm{Fe}$ in the dry material of the different residues showed a higher potential in proportion to nutrient and $\mathrm{pH}$ in the soil. In fact, in acidic soils, the availability of $\mathrm{Fe}$ is higher than that in increased $\mathrm{pH}$. Decrease up to $0.5 \mathrm{pH}$ units may be important in metal availability in the soil (Hooda and Alloway, 1996). This fact could explain an 
increase in availability of $\mathrm{Fe}$ with a decrease of $\mathrm{pH}$, as reported in current research.

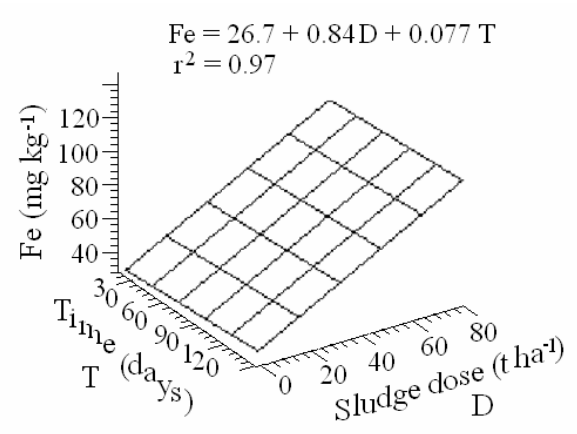

(a) Harvest 1 (conventional or Summer harvest)

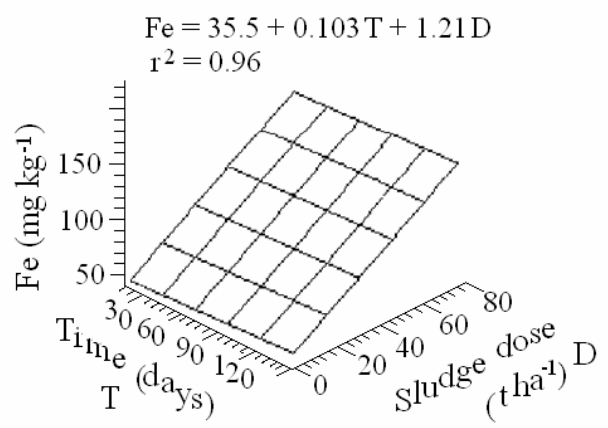

(c) Harvest 3 (conventional or Summer harvest)

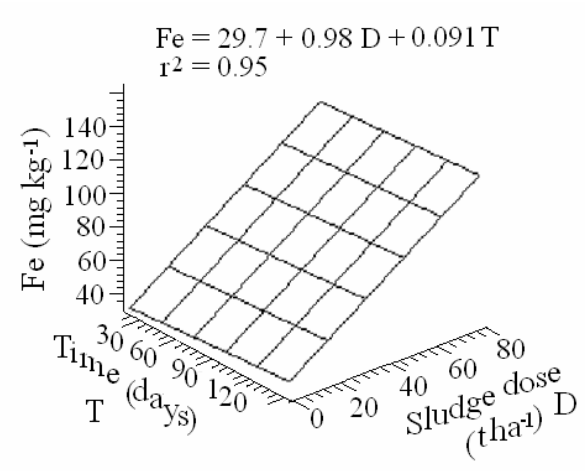

(b) Harvest 2 (Winter harvest)

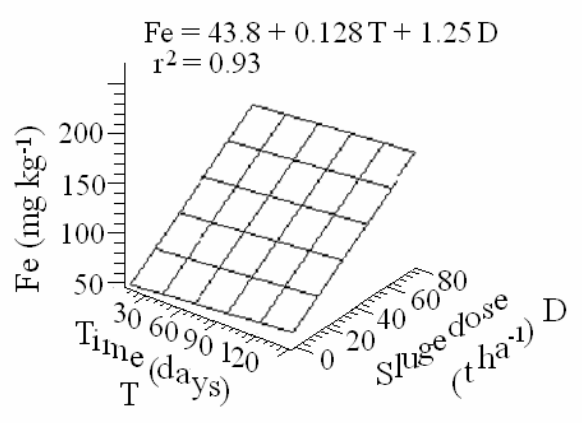

(d) Harvest 4 (Winter harvest)

Figure 4 - Variation in average rates for Fe: (a) Harvest 1, (b) Harvest 2, (c) Harvest 3 and (d) Harvest 4, removed by DTPA pH 7.3 on applying sewage sludge in the four harvests.

\section{CONCLUSIONS}

- Successive applications of sewage sludge in soil showed an increase in CEC and, at the same time, a decrease in $\mathrm{pH}$; later, CEC became constant and close to start rate.

- Heavy metals, non-essential to plants, showed concentrations lower than the analytic method's detection limits.

- $\mathrm{Fe}$ and Mn rates in soil gradually increased according to rise of sewage sludge doses.

- Effects of sewage sludge application could be taken as a source of essential metals.

\section{RESUMO}

A reciclagem agrícola do lodo de esgoto tem provocado o acúmulo de metais pesados no solo e na água, podendo atingir níveis tóxicos e causar danos às plantas cultivadas, aos animais e ao homem, por meio da cadeia trófica. Neste intuito foi desenvolvido o presente experimento, em condições de campo, entre 2000 e 2002, onde foram avaliados os efeitos da aplicação de lodo de esgoto por dois anos, sobre a extração de metais de transição (essenciais e não) pelo extrator DTPA em um Latossolo Vermelho distrófico (LVd) de textura média. As concentrações dos elementos metálicos: $\mathrm{Mn}, \mathrm{Fe}, \mathrm{Cd}, \mathrm{Ni}, \mathrm{Co}, \mathrm{Pb}$ e $\mathrm{Cr}$ não foram detectados pelo método da absorção atômica na solução obtida com o extrator DTPA. A aplicação de lodo de esgoto causou inicialmente pequena 
elevação no $\mathrm{pH}$ do solo, posteriormente a diminuição do mesmo, e manteve-se próximo ao original. Foi possível concluir que, com a aplicação consecutiva do lodo, os teores extraíveis de $\mathrm{Fe}$ e $\mathrm{Mn}$ nas amostras de solos aumentaram gradativamente nos dois anos agrícolas, com as doses do lodo de esgoto aplicado, época de amostragens, e foram superiores ao tratamento testemunha. O extrator apresentou capacidade restrita para avaliação da fitodisponibilidade dos metais pesados decorrentes das baixas concentrações nas amostras de solo.

\section{REFERENCES}

Andreoli, C. V. and Bonnet, B. R. P. (Orgs.) (1998), Manual de métodos para análises microbiológicas e parasitológicas em reciclagem agrícola de lodo de esgoto. Curitiba: SANEPAR.

Andreoli, C. V. and Fernandes, F. (1997), Principais fatores limitantes - metais pesados e patógenos - para o uso agrícola do lodo de esgotos no Paraná. Sanare, Curitiba, 7 : (7), 68-72.

Anjos, A. R. M. (1999), Lixiviação de espécies químicas em Latossolos sucessivamente tratados com biossólido e disponibilidade de metais pesados para plantas de milho. Doctoral Thesis, Escola Superior de Agricultura "Luiz de Queiroz", Universidade de São Paulo, Piracicaba, Brasil.

Berton, R. S.; Camargo, A. O. and Valadares, J. M. A. S. (1989), Absorção de nutrientes pelo milho em reposta à adição de lodo de esgoto a cinco solos paulistas. Rev. Bras. Ci. Solo, Campinas, 13 : (2), 187-192.

Bertoncini, E. I. (1997), Mobilidade de metais pesados em solos tratados com lodo de esgoto. Master's Thesis, Escola Superior de Agricultura "Luiz de Queiroz”, Universidade de São Paulo, Brasil.

Bertoncini, E. I. and Matiazzo, M. E. (1999), Lixiviação de metais pesados em solos tratados com lodo de esgoto. Rev. Bras. Ci. Solo, Campinas, 23 : (3), 737-744.

Borkert, C. M.; Pavan, M. A. and Bataglia, O. C. (2001), Disponibilidade e avaliação de elementos catiônicos: ferro e manganês. In: Micronutrientes $e$ elementos tóxicos na agricultura. Jaboticabal, SP: CNPq/ FAPESP/POTAFOS. pp. 151-185.

Cavallaro, N.; Padilla, N. and Villaruda, J. (1993), Sewage effects on chemical properties of acid soils. Soil Sci., Baltimore, 156 : (2), 63-70.

Chang, A. C.; Hyun, H. and Page, A. L. (1997), Cadmium uptake for Swiss chard grown on composted sewage sludge treated field plots: plateau or time bomb? J. Environ. Qual., Madison, 26, 11-19.
Chang, A. C. (1987), Effects of long term sludge application on accumulation of trace elements by crops. In: Page, A. L.; Logan; T. J., Ryan, J. A land application of sludge-food chain implications. Chelsea, USA: Lewis Publishers. pp. 53-66.

Curi, N.; Larach, J. O. I.; Kämpf, N.; Moniz, A. C. and Fontes, L. E. F. (1993), Vocabulário de ciência do solo. Campinas: Sociedade Barasileira de Solos.

Dias, F. L. F. (1994), Efeito da aplicação de calcário, lodo de esgoto e vinhaça em solo cultivado com sorgo gramífero (Sorghum bicolor L. Moench). Undergraduate Research, Faculdade de Ciências Agrárias e Veterinárias, Universidade Estadual Paulista, Jaboticabal, Brasil.

Dowdy, R. H.; Lapterell, J. J.; Hinesly, T. D.; Grossnman, R. B. and Sullivan, D. L. (1991), Trace metal movement in an aeric ochraqualf following 14 years of annual sludge applications. J. Environ. Qual., Madison, 20 : (1), 119-123.

Glória, N. A. (1992), Uso agronômico de resíduos. In: Reunião Brasileira de Fertilidade do Solo e Nutrição de Plantas, Piracicaba. Anais... Campinas: Fundação Cargill. pp. 195-212.

Hooda, P. S. and Alloway, B. J. (1996), The effect of liming on heavy metal concentrations in wheat, carrots and spinach grown on previously applied soils. J. Agric. Sci., Cambridge, 127, 289-294.

Horwitz, W. (Ed.) (1980), Official Methods of Analysis of the Association of Official Analytical Chemists. 13. ed. Association of Official Analytical Chemists (AOAC), Washington, USA.

Instituto Agronômico do Paraná. (1992), Manual de análise química de solo e controle de qualidade. Londrina: IAPAR.

Lindsay, W. L. and Norwell, W. A. (1978), Development of DTPA soil test for zinc, iron, manganese and copper. Soil Sci. Soc. Am. J., Madison, 42, 421-428.

Logan, T. J. and Chaney, R. L. (1983), Metals. In: Workshop on Utilization of Municipal Wastewater and sludge on land, Riverside, California. Proceedings... California. pp.235-323.

Logan, T. J.; Lindsay, B. J.; Goins, L. E. and Ryan, J. A. (1997), Field Assessment of sludge metal bioavailability to crops: sludge rate response. $J$. Environ. Qual., Madison, 26 : (2), 534-550.

Long, G. L. and Winefordner, J. D. (1983), Limit of detection - a closer look at the IUPAC definition. An. Chem., 55 : (7), 712A-724A.

Marques, M. O. (1996), Incorporação de lodo de esgoto em solo cultivado com cana-de-açúcar. $111 \mathrm{ff}$. $\mathrm{PhD}$ Thesis, Faculdade de Ciências Agrárias e Veterinárias, Universidade Estadual Paulista, Jaboticabal, Brasil.

Matos. A. T.; Fontes, M. P. F.; Jordão, C. P. and Costa, L. M. (1996), Mobilidade e formas de retenção de metais pesados em Latossolo Vermelho Amarelo. Rev. Bras. Ci. Solo, Campinas, 20, 379-386. 
Melo, W. J.; Marques, M. O.; Santiago, G. and Ceite, S. A. S. (1994), Efeito de doses crescentes de lodo de esgoto sobre frações na matéria orgânica e CTC de um latossolo cultivado com cana-de-açúcar. Rev. Bras. Ci. Solo, Campinas, 18, 449-455.

Oliveira, F. C. (2000), Disposição de lodo de esgoto e composto de lixo num Latossolo Vermelho Amarelo cultivado com cana-de-açúcar. Doctoral Thesis, Escola Superior de Agricultura "Luiz de Queiroz", Universidade de São Paulo, Piracicaba. Brasil.

Oliveira. F. C. (1995), Metais pesados e formas nitrogenadas em solos tratados com lodo de esgoto. Master's Thesis, Escola Superior de Agricultura "Luiz de Queiroz". Universidade de São Paulo, Piracicaba, Brasil.

Page, A. L.; Logan, T. J. and Ryan, J. A. (1987), Land application of sludge - food chain implications. Chelsea, USA: Lewis Publishers.

Petruzzelli, G. (1989), Recycling wastes in agriculture: heavy metal bioavailability. Agriculture, Ecosystems Environ., 27 : (1/4), 493-503.

Pietz, R. I.; Carlson, C. R.; Peterson Jr., J. R.; Zenz, B. R. and Lu-Hing, C. (1989), Application of sewage sludge and other amendments to coal refuse material: III. Effects on percolate water composition. $J$. Environ. Qual., Madison, 18, 174-179.

Pigozzo, A. T. J.; Gobbi, M. A. and Lenzi, E. (2000), Effects of the application of sewage sludge and fowl manure on soils of. Paraná State in maize plants (Zea mays L.) as a micro-nutrients source. Braz. Arch. Biol. Technol., 43 : (2), 151-157.
Raij, B. van, (1998), Uso agrícola de biossólidos. In: Seminário Sobre Gerenciamento de Biossólidos do Mercosul, Curitiba, PR. Anais... Curitiba. pp. 147-151.

Regazzi, A. T. and Campos, H. A. (1988), Decomposição da soma de Quadrados do Resíduo (a) numa análise de Variância de Ensaios em parcelas subdivididas, no caso em que nem todos os tratamentos principais têm Tratamentos Secundários. Rev. Ceres, 35 : (199), 283-296,.

Silva, F. C. (1995), Uso agronômico de lodo de esgoto: efeitos em fertilidade do solo e qualidade da cana-deaçúcar. Doctoral Thesis, Escola Superior de Agricultura "Luiz de Queiroz", Universidade de São Paulo, Piracicaba, Brasil.

Simonete, M. A. (2001), Alterações nas propriedades químicas de um argissolo adubado com lodo de esgoto e desenvolvimento e acúmulo de nutrientes em plantas de milho. Doctoral Thesis, Escola Superior de Agricultura Luiz de Queiroz, Universidade de São Paulo, Piracicaba, Brasil.

Tisdale, S. L.; Nelson, W. L. and Beaton, J. D. (1985), Quantitative chemical analysis. London: Macmillan. 1190 pp.

Welz, B. and Sperling, M. (1999), Atomic absorption spectrometry. $3^{\text {rd }}$ rev. ed. Weinheim: VCH Verlagsgesellschaft $\mathrm{mbH}$. 